EISSN: 2706-7955 ISSN: 2077-4605

DOI: $10.36632 /$ mejar/2021.10.2.39

Journal homepage: www.curresweb.com

Pages: 539-547

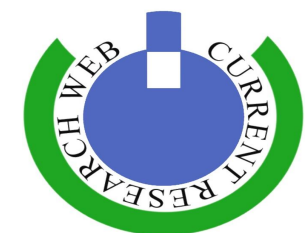

\title{
Influence of Residual Allelopathic Effects of the Seed Powder of Watercress or Mustard on the Following Cowpea Plant and Its Associated Weeds
}

\author{
Mahmoud A. T. El-Dabaa, Salah El-Din A. Ahmed, Nadia K. Messiha, Ebrahim R. El- \\ Desoki and Raafat R. El-Masry
}

Botany Department, Weed Biology and Control, National Research Centre, $33^{\text {th }}$ El Bohouth St. Dokki, P.O. Box 12622, Cairo, Egypt.

Received: 10 March $2021 \quad$ Accepted: 20 April $2021 \quad$ Published: 30 April 2021

\begin{abstract}
Cowpea (Vigna unguiculata (L.) Walp.) plants were sown in the same pots after the harvest of tomato plants which were previously treated with different rates $(5,10,15,30$ and $45 \mathrm{~g} / \mathrm{kg}$ soil $)$ of seed powder of two Brassicaceae plants, watercress (Eruca Sativa M.) or mustard (Sinapis alba L.) compared to those treated with Basamid herbicide at $0.2 \mathrm{~g} /$ pot. This work was done in the greenhouse of the Egyptian National Research Centre during the two successive summer seasons of 2017 and 2018. The obtained results indicated that all previous treatments used to tomato were significantly minimized the weight (fresh and dry) of grasses, broad-leaved and the total weeds associated with the following cowpea plants, at 45 and 85 days after sowing (DAS). Generally, all treatments with watercress were more effective than mustard in controlling both broad leaved weeds and grasses. Moreover, broad leaved weeds were more susceptible than grasses. The results also showed that all mentioned treatments had significant effect on cowpea plants, significantly increasing most growth parameters and yield and yield components. The results indicated that all tested treatments had no toxic effects on the following cowpea plants.
\end{abstract}

Keywords: Basamid herbicide, cowpea, mustard, residual effect, tomato, watercress.

\section{Introduction}

Cowpea (Vigna unguiculata (L.) Walp.) is a multifunctional food crop for humans and animals. Cowpeas are vital to the livelihood of the poor people in tropical least developed countries. Its seeds are composed of $53 \%$ carbohydrates, $24 \%$ crude protein and $2 \%$ fat (FAO, 2012). In addition to its importance as human food, cowpea is also useful for soil fertilization through symbiotic nitrogen fixation and can be a major animal feed due to the nutiritive quality of its leaves (Diouf, 2011).Since ancient times, weeds are recognized as plant pests (Zimdahl, 2013) as it cause serious damage and considerable loss in the productivity of crops through a continuous competition with crops for the solar radiation, space, soil nutrients and water. Harnessing the allelopathic phenomenon is one of the important innovative weed control methods used to suppress weeds (Jabran and Farooq, 2013 and Zeng, 2014). Fighting the implications of weeds in crop production is the main aim of the practical allelopathic applications for weed control in agricultural systems. Jabran et al. (2015) discussed using allelopathic cover crops and residues as well as their rotational sowing for practical weed control in field crops. A strong allelopathic potential has been demonstrated for the Brassicaceae family against other crops and weed plants (Haramoto and Gallandt, 2004; El-Dabaa et al., 2019: El-Masry et al., 2019). Brassicas produce glucosinolates as allelochemical compounds, through their plant parts with different concentrations (Fahey et al., 2001). Several biologically active compounds (allelochemicals) such as isothiocyanates, nitriles, thiocyanates, epithionitriles and oxazoiolines are produced from the decomposition of glucosinolates which have been released into the environment through volatilization (Morra and Kirkegaard, 2002 and Bones and Rossiter, 2006). These allelochemicals, mainly

Corresponding Author: Mahmoud A.T. El-Dabaa, Botany Department, Weed Biology and Control, National Research Centre, $33^{\text {th }}$ El Bohouth St. Dokki, P.O. Box 12622, Cairo, Egypt.

E-mail: eldabaam@yahoo.com 


\subsection{Chemical measurements}

A) Determination of total glucosinolates $(\mu \mathrm{mol} / \mathrm{g} \mathrm{DW})$

Total glucosinolates were extracted from dry seed powder of watercress or mustard. According to Rauchberger et al., (1979), glucosinolates were determined by colorimetrical measurement of the glucose released during hydrolysis by myrosinase enzyme (Nasirullah and Krishnamurthy, 1996).

\section{B) Determination of total phenolic content ( $\mathrm{mg} / \mathrm{g} \mathrm{DW})$}

A colorimetrical determination of total phenolic content in the seed powder of watercress or mustard was carried out according to Snell and Snell (1953).

\subsection{Statistical Analysis}

A statistical analysis was performed on all results according to the Snedecor and Cochrans (1980) where LSD at 5\% probability level was used to compare treatment means.

\section{Results and Discussion}

\subsection{Residual effect from the previous tomato treatments on the associated summer weeds grown with cowpea plants}

It is evident from the data in Tables 1 and 2 that all of the previous tomato treatments significantly reduced both fresh and dry weights of broad-leaved, grasses and the total weeds associated with the following cowpea crop at 45 and 85 days after sowing (DAS) as compared to infected control (Tomato + Broomrape). In the two growth ages, 45 and $85 \mathrm{DAS}$, the broad-leaved weeds disappeared with treatments of 30 and $45 \mathrm{~g} / \mathrm{kg}$ soil of watercress, $45 \mathrm{~g} / \mathrm{kg}$ soil of mustard and the $0.2 \mathrm{~g} /$ pot of Basamid treatments. The reduction rate of fresh and dry weight of grasses and total weeds was found to increase by increasing the rate used for both watercress and mustard. The highest reduction in the dry weight of grasses and total weeds were recorded as follow: $45 \mathrm{~g} / \mathrm{kg}$ soil of watercress, $0.2 \mathrm{~g} /$ pot were of Basamid herbicide, $30 \mathrm{~g} / \mathrm{kg}$ soil watercress as well as $45 \mathrm{~g} / \mathrm{kg}$ soil mustard treatments. These treatments reduced the dry weight of the total weeds at 85 DAS to $86.59,75.45,69.18$ and $66.03 \%$, respectively when compared to infected control.

Table1: The allelopathic influence of the seed powder of watercress and mustard as well as Basamid rates previously applied to the winter tomato plants on the fresh and dry weight of weeds grown with cowpea plants at 45 days after sowing (g/pot) (Average results of 2017 and 2018 experiments).

\begin{tabular}{|c|c|c|c|c|c|c|}
\hline \multirow{2}{*}{ Previous treatments } & \multicolumn{3}{|c|}{ Fresh weight of weeds (gm) } & \multicolumn{3}{|c|}{ Dry weight of weeds (gm) } \\
\hline & Broad- leaved & Grasses & Total & Broad- leaved & Grasses & Total \\
\hline $\mathbf{T}_{1}$ & 40.90 & 115.0 & 155.90 & 12.58 & 23.65 & 36.23 \\
\hline $\mathbf{T}_{2}$ & 16.55 & 89.0 & 105.55 & 3.28 & 18.33 & 21.61 \\
\hline $\mathbf{T}_{3}$ & 13.30 & 79.1 & 92.40 & 2.63 & 16.31 & 18.94 \\
\hline $\mathbf{T}_{4}$ & 4.00 & 55.1 & 59.10 & 1.00 & 11.20 & 12.20 \\
\hline $\mathbf{T}_{5}$ & 0.00 & 45.5 & 45.50 & 0.00 & 9.68 & 9.68 \\
\hline T6 & 0.00 & 32.9 & 32.90 & 0.00 & 9.01 & 9.01 \\
\hline $\mathbf{T}_{7}$ & 22.80 & 100.5 & 123.30 & 4.52 & 20.68 & 25.20 \\
\hline $\mathbf{T}_{8}$ & 16.75 & 94.2 & 110.95 & 3.32 & 19.40 & 22.72 \\
\hline $\mathbf{T}_{9}$ & 13.15 & 73.5 & 86.65 & 2.60 & 15.15 & 17.75 \\
\hline$T_{10}$ & 1.70 & 68.6 & 70.30 & 0.62 & 14.15 & 14.77 \\
\hline $\mathbf{T}_{11}$ & 0.00 & 50.8 & 50.80 & 0.00 & 10.50 & 10.50 \\
\hline $\mathbf{T}_{12}$ & 0.00 & 43.5 & 43.50 & 0.00 & 9.42 & 9.42 \\
\hline L.S.D.0.05 & 1.58 & 3.0 & 2.01 & 0.72 & 1.55 & 1.84 \\
\hline
\end{tabular}

$\mathbf{T}_{1}$ Tomato + Broomrape (Infected control).

$\mathbf{T}_{2}$ Tomato + Broomrape + Watercress at $5 \mathrm{~g} / \mathrm{kg}$ soil

$\mathbf{T}_{3}$ Tomato + Broomrape + Watercress at $10 \mathrm{~g} / \mathrm{kg}$ soil

$\mathbf{T}_{4}$ Tomato + Broomrape + Watercress at $15 \mathrm{~g} / \mathrm{kg}$ soil

$\mathbf{T}_{\mathbf{5}}$ Tomato + Broomrape + Watercress at $30 \mathrm{~g} / \mathrm{kg}$ soil

$\mathbf{T}_{6}$ Tomato + Broomrape + Watercress at $45 \mathrm{~g} / \mathrm{kg}$ soil
$\mathbf{T}_{7}$ Tomato + Broomrape + Mustard at $5 \mathrm{~g} / \mathrm{kg}$ soil

T8 Tomato + Broomrape + Mustard at $10 \mathrm{~g} / \mathrm{kg}$ soil

T9 Tomato + Broomrape + Mustard at $15 \mathrm{~g} / \mathrm{kg}$ soil

$\mathbf{T}_{\mathbf{1 0}}$ Tomato + Broomrape + Mustard at $30 \mathrm{~g} / \mathrm{kg}$ soil

$\mathbf{T}_{11}$ Tomato + Broomrape + Mustard at $45 \mathrm{~g} / \mathrm{kg}$ soil

$\mathbf{T}_{12}$ Tomato + Broomrape + Basamid $0.2 \mathrm{~g} /$ pot 
Table 2: The allelopathic influence of the seed powder of watercress and mustard as well as Basamid rates previously applied to the winter tomato plants on the fresh and dry weight of weeds grown with cowpea plants at 85 days after sowing (g/pot) (Average results of 2017 and 2018 experiments).

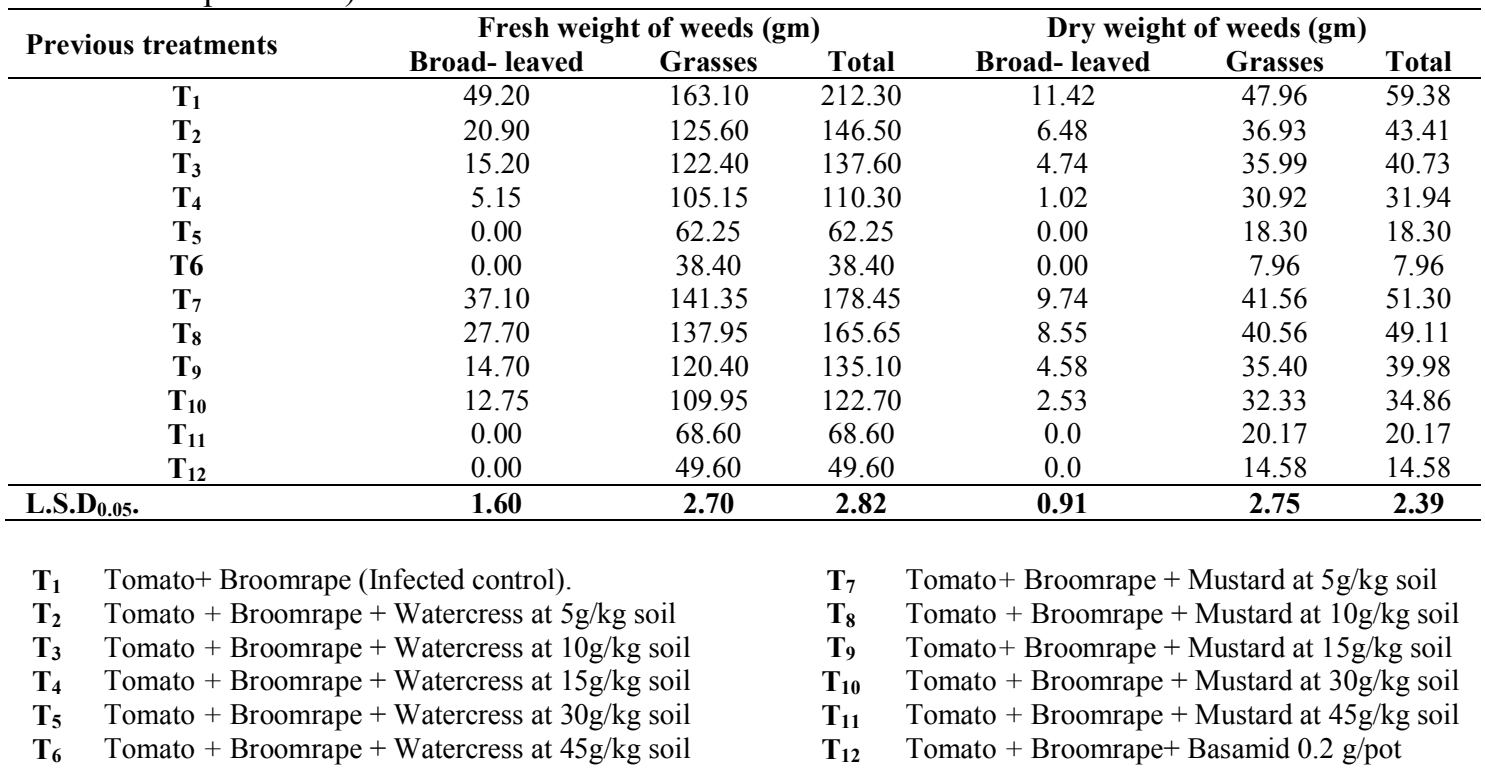

\subsection{Residual effect from the previous tomato treatments on the growth of cowpea}

Results presented in Tables 3 and 4 indicate that all previous treatments of tomato pots were significantly increased all cowpea growth parameters in the two ages of growth (45 and 85 DAS) except for watercress treatment at $5 \mathrm{~g} / \mathrm{kg}$ soil on the number of branches/plant at 85 DAS as well as mustard treatments at 5 and $10 \mathrm{~g} / \mathrm{kg}$ soil on some growth characters at 45 and 85 DAS. All growth characters were found to increase by increasing the rate used of both watercress and mustard. The highest values of cowpea dry weight were recorded respectively at 85 DAS with these treatments as follow: $45 \mathrm{~g} / \mathrm{kg}$ soil watercress, $0.2 \mathrm{~g} /$ pot Basamid herbicide, $30 \mathrm{~g} / \mathrm{kg}$ soil watercress and $45 \mathrm{~g} / \mathrm{kg}$ soil mustard treatments. These increases reach to $159.85,137.81,124.26$ and 123.03, respectively over the infected control.

Table 3: The allelopathic influence of the seed powder of watercress and mustard as well as Basamid rates previously applied to the winter tomato plants on the following cowpea plant growth at 45 days after sowing. (Average results of 2017 and 2018 experiments).

\begin{tabular}{ccccc}
\hline Previous treatments & Plant height $(\mathbf{c m})$ & Leaves number/plant & Plant fresh weight (g) & Plant dry weight (g) \\
\hline $\mathbf{T}_{\mathbf{1}}$ & 49.8 & 11.5 & 31.18 & 5.00 \\
$\mathbf{T}_{\mathbf{2}}$ & 60.3 & 13.4 & 39.93 & 6.52 \\
$\mathbf{T}_{\mathbf{3}}$ & 64.1 & 13.8 & 40.17 & 6.60 \\
$\mathbf{T}_{\mathbf{4}}$ & 69.7 & 14.5 & 49.10 & 7.35 \\
$\mathbf{T}_{\mathbf{5}}$ & 75.9 & 15.8 & 55.10 & 9.00 \\
$\mathbf{T}_{\mathbf{6}}$ & 79.3 & 16.5 & 58.60 & 9.60 \\
$\mathbf{T}_{\mathbf{7}}$ & 52.0 & 12.5 & 35.00 & 5.22 \\
$\mathbf{T}_{\mathbf{8}}$ & 53.5 & 13.0 & 37.58 & 5.80 \\
$\mathbf{T}_{\mathbf{9}}$ & 64.3 & 13.8 & 41.85 & 6.70 \\
$\mathbf{T}_{\mathbf{1 0}}$ & 68.3 & 14.0 & 45.70 & 7.11 \\
$\mathbf{T}_{\mathbf{1 1}}$ & 75.3 & 15.3 & 54.80 & 8.69 \\
$\mathbf{T}_{\mathbf{1 2}}$ & 77.0 & 16.0 & 57.90 & 9.10 \\
L.S.D. & 2.7 & 1.3 & 2.26 & 1.24 \\
\hline
\end{tabular}

$\mathbf{T}_{1}$ Tomato + Broomrape (Infected control).

$\mathbf{T}_{\mathbf{2}}$ Tomato + Broomrape + Watercress at $5 \mathrm{~g} / \mathrm{kg}$ soil

$\mathbf{T}_{3}$ Tomato + Broomrape + Watercress at $10 \mathrm{~g} / \mathrm{kg}$ soil

$\mathbf{T}_{4}$ Tomato + Broomrape + Watercress at $15 \mathrm{~g} / \mathrm{kg}$ soil

$\mathbf{T}_{\mathbf{5}}$ Tomato + Broomrape + Watercress at $30 \mathrm{~g} / \mathrm{kg}$ soil

$\mathbf{T}_{6}$ Tomato + Broomrape + Watercress at $45 \mathrm{~g} / \mathrm{kg}$ soil
$\mathbf{T}_{7}$ Tomato + Broomrape + Mustard at $5 \mathrm{~g} / \mathrm{kg}$ soil

$\mathbf{T}_{\mathbf{8}}$ Tomato + Broomrape + Mustard at $10 \mathrm{~g} / \mathrm{kg}$ soil

$\mathbf{T}_{9}$ Tomato + Broomrape + Mustard at $15 \mathrm{~g} / \mathrm{kg}$ soil

$\mathbf{T}_{10}$ Tomato + Broomrape + Mustard at $30 \mathrm{~g} / \mathrm{kg}$ soil

$\mathbf{T}_{11}$ Tomato + Broomrape + Mustard at $45 \mathrm{~g} / \mathrm{kg}$ soil

$\mathbf{T}_{12}$ Tomato + Broomrape+ Basamid $0.2 \mathrm{~g} /$ pot 
Table 4: The allelopathic influence of the seed powder of watercress and mustard as well as Basamid rates previously applied to the winter tomato plants on the following cowpea plant growth at 85 days after sowing. (Average results of 2017 and 2018 experiments).

\begin{tabular}{cccccc}
\hline Previous treatments & $\begin{array}{c}\text { Plant height } \\
(\mathbf{c m})\end{array}$ & $\begin{array}{c}\text { Leaves } \\
\text { number } \\
\text { /plant }\end{array}$ & $\begin{array}{c}\text { Branches } \\
\text { number / } \\
\text { plant }\end{array}$ & $\begin{array}{c}\text { Plant fresh } \\
\text { weight (g) }\end{array}$ & $\begin{array}{c}\text { Plant dry } \\
\text { weight (g) }\end{array}$ \\
\hline $\mathbf{T}_{\mathbf{1}}$ & 112.0 & 14.0 & 1.0 & 46.8 & 8.12 \\
$\mathbf{T}_{\mathbf{2}}$ & 119.5 & 19.0 & 1.5 & 62.1 & 10.09 \\
$\mathbf{T}_{\mathbf{3}}$ & 125.0 & 19.5 & 1.7 & 71.7 & 10.75 \\
$\mathbf{T}_{\mathbf{4}}$ & 132.5 & 21.0 & 2.3 & 83.0 & 13.78 \\
$\mathbf{T}_{\mathbf{5}}$ & 152.9 & 24.0 & 3.0 & 105.0 & 18.21 \\
$\mathbf{T}_{\mathbf{6}}$ & 160.0 & 27.0 & 3.5 & 110.5 & 21.10 \\
$\mathbf{T}_{\mathbf{7}}$ & 116.5 & 16.9 & 1.1 & 56.5 & 9.32 \\
$\mathbf{T}_{\mathbf{8}}$ & 117.0 & 17.0 & 1.3 & 60.0 & 9.55 \\
$\mathbf{T}_{\mathbf{9}}$ & 126.5 & 20.0 & 2.0 & 73.0 & 11.70 \\
$\mathbf{T}_{\mathbf{1 0}}$ & 129.5 & 20.9 & 2.1 & 80.5 & 12.79 \\
$\mathbf{T}_{\mathbf{1 1}}$ & 152.0 & 23.8 & 2.8 & 96.0 & 18.11 \\
$\mathbf{T}_{\mathbf{1 2}}$ & 156.5 & 25.0 & 3.2 & 107.0 & 19.31 \\
\hline L.S.D.0.05 & $\mathbf{3 . 7}$ & $\mathbf{2 . 3}$ & $\mathbf{0 . 6}$ & $\mathbf{2 . 9}$ & $\mathbf{1 . 5 0}$ \\
\hline
\end{tabular}

T1 Tomato + Broomrape (Infected control).

$\mathbf{T}_{2}$ Tomato + Broomrape + Watercress at $5 \mathrm{~g} / \mathrm{kg}$ soil

$\mathbf{T}_{3}$ Tomato + Broomrape + Watercress at $10 \mathrm{~g} / \mathrm{kg}$ soil

$\mathbf{T}_{4}$ Tomato + Broomrape + Watercress at $15 \mathrm{~g} / \mathrm{kg}$ soil

$\mathbf{T}_{\mathbf{5}}$ Tomato + Broomrape + Watercress at $30 \mathrm{~g} / \mathrm{kg}$ soil

$\mathbf{T}_{6}$ Tomato + Broomrape + Watercress at $45 \mathrm{~g} / \mathrm{kg}$ soil
$\mathbf{T}_{7}$ Tomato + Broomrape + Mustard at $5 \mathrm{~g} / \mathrm{kg}$ soil

T8 Tomato + Broomrape + Mustard at $10 \mathrm{~g} / \mathrm{kg}$ soil

T9 Tomato + Broomrape + Mustard at $15 \mathrm{~g} / \mathrm{kg}$ soil

$\mathbf{T}_{10}$ Tomato + Broomrape + Mustard at $30 \mathrm{~g} / \mathrm{kg}$ soil

$\mathbf{T}_{11}$ Tomato + Broomrape + Mustard at $45 \mathrm{~g} / \mathrm{kg}$ soil

$\mathbf{T}_{12}$ Tomato + Broomrape + Basamid $0.2 \mathrm{~g} /$ pot

\subsection{Residual effect from the previous tomato treatments on the yield and yield components of cowpea}

The yield of cowpea and its components; i.e. pods number / pot, pods fresh and dry weight /pot, length of pod $(\mathrm{cm})$, seeds number /pod, seeds weight / 10 pods $(\mathrm{g})$ and weight of 100 seeds $(\mathrm{g})$ are presented in Table-5. Results demonstrated that all of the previous treatments to tomato pots of watercress and mustard as well as $0.2 \mathrm{~g} /$ pot Basamid herbicide had significant effect on all cowpea yield and its components except the lowest rate $(5 \mathrm{~g} / \mathrm{kg}$ soil) from the watercress seed powder on the weight of 100 seeds $(\mathrm{g})$ and also mustard treatments at 5 and $10 \mathrm{~g} / \mathrm{kg}$ soil on some yield components characters. The increase in the cowpea yield and its components was rate dependent of both watercress and mustard seed powder used. The highest values of the seeds weight $/ 10$ pods $(\mathrm{g})$ and the weight of 100 seeds $(\mathrm{g})$ were recorded respectively with those of the previous tomato treatments as follow: $45 \mathrm{~g} / \mathrm{kg}$ soil watercress, $0.2 \mathrm{~g} /$ pot Basamid herbicide, $30 \mathrm{~g} / \mathrm{kg}$ soil watercress and $45 \mathrm{~g} / \mathrm{kg}$ soil mustard comparing with infected control. These increases reached to $106.25,93.75,81.25$ and $68.75 \%$, for the seeds weight $/ 10$ pods (g), while the weight of 100 seeds $(\mathrm{g})$ reached to $42.11,36.84,36.84$ and $31.58 \%$ respectively more than the infected control. It is clearly noticed that the infected control recorded the lowest values of growth at both ages (45 and 85 DAS) as well as the cowpea yield and its components.

\subsection{The content of total glucosinolates and total phenolics in the seed powder of watercress and mustard.}

Total glucosinolates and total phenolics contents determined in the extracts of both watercress and mustard seed powder are represented in Table- 6 .

In Egypt, tomato cultivation could be followed by a summer crop such as cowpea in order to increase the Egyptian crop area per year. Therefore, it was thought advisable to study the residual effect of the seed powder of watercress or mustard plants of the Brassicaceae family, and Basamid herbicide as previous tomato treatment on the following summer cowpea plants.

Generally, the previously used treatments with either the seed powder of the two Brassicaceae plants or Basamid herbicide decreased the fresh and dry weight of broad-leaved weeds as well as grasses which are associated with the growth of the following cowpea plants. In this connection it should be mentioned that the present investigation and our previous report (Ahmed et al., 2020 b) are well 
supported by the previous findings of Wolf et al., 1984, Teasdale and Taylorson, 1986, Bialy et al., 1990 Choesin and Boerner, 1990 and Petersen et al., 2001 which showed that the degradation products from the previously added seed powder from the two mentioned Brassicaceae plants contain Glucosinolates hydrolysis products which could inhibit the germination of many different seeds.

The results of the present investigation indicate that most of the previously mentioned treatments had significant effect on the growth of cowpea plants and increased yield as well as its components. These results confirm the previous work which showed that the seed powder of the two mentioned Brassicaceae plants had a stimulatory effect on the preceding crop plant (Vilhorde et al., 1985; Angus et al., 1991; Oliva et al., 2002;; Ahmed et al., 2018; El-Dabaa et al., 2019; El-Masry et al., 2019 and El- Wakeel et al., 2019). Similar reports showed that other Brassicaceae plants when incorporated into the soil as a green manure decreased the growth of emerging weeds in the following crop (Boydston and Hang, 1995; Al-Khatib et al., 1997 and Krishnan et al., 1998).

Table 5: Allelopathic influence of the seed powder of watercress and mustard as well as Basamid rates previously applied to the winter tomato plants on the following cowpea yield and yield components at harvest. (Average results of 2017 and 2018 experiments).

\begin{tabular}{cccccccc}
\hline & $\begin{array}{c}\text { Pods } \\
\text { number } \\
\text { Previous treatments }\end{array}$ & $\begin{array}{c}\text { Pods } \\
\text { F.W./ } \\
\text { pot }(\mathbf{g})\end{array}$ & $\begin{array}{c}\text { Pods } \\
\text { D.W./ } \\
\text { pot }(\mathbf{g})\end{array}$ & $\begin{array}{c}\text { Pod } \\
\text { length } \\
\text { (cm) }\end{array}$ & $\begin{array}{c}\text { Seeds No. } \\
\text { /pod }\end{array}$ & $\begin{array}{c}\text { Seeds } \\
\text { weight } \\
\text { /10pods(g) }\end{array}$ & $\begin{array}{c}\text { Wt. of } \\
\mathbf{1 0 0} \\
\text { seeds } \\
\text { (g) }\end{array}$ \\
\hline $\mathbf{T}_{\mathbf{1}}$ & 16 & 33 & 27 & 15.6 & 6.8 & 16 & 19 \\
$\mathbf{T}_{\mathbf{2}}$ & 21 & 44 & 36 & 17.2 & 8.7 & 20 & 21 \\
$\mathbf{T}_{\mathbf{3}}$ & 23 & 47 & 39 & 17.6 & 9.4 & 21 & 22 \\
$\mathbf{T}_{\mathbf{4}}$ & 33 & 84 & 73 & 19.4 & 11.1 & 25 & 24 \\
$\mathbf{T}_{\mathbf{5}}$ & 43 & 120 & 100 & 20.3 & 12.0 & 29 & 26 \\
$\mathbf{T}_{\mathbf{T}}$ & 56 & 136 & 113 & 21.2 & 12.5 & 33 & 27 \\
$\mathbf{T}_{\mathbf{7}}$ & 18 & 39 & 32 & 16.4 & 8.0 & 18 & 20 \\
$\mathbf{T}_{\mathbf{9}}$ & 20 & 42 & 35 & 16.8 & 8.3 & 19 & 21 \\
$\mathbf{T}_{\mathbf{1 0}}$ & 25 & 57 & 47 & 18.3 & 9.9 & 23 & 23 \\
$\mathbf{T}_{\mathbf{1 1}}$ & 27 & 64 & 53 & 18.7 & 10.4 & 24 & 23 \\
$\mathbf{T}_{\mathbf{1 2}}$ & 41 & 99 & 86 & 20.0 & 11.5 & 27 & 25 \\
L.S.D.0.05 & 48 & 130 & 108 & 20.9 & 12.2 & 31 & 26 \\
\hline
\end{tabular}

T1 Tomato + Broomrape (Infected control).

$\mathbf{T}_{2}$ Tomato + Broomrape + Watercress at $5 \mathrm{~g} / \mathrm{kg}$ soil

$\mathbf{T}_{3}$ Tomato + Broomrape + Watercress at $10 \mathrm{~g} / \mathrm{kg}$ soil

$\mathbf{T}_{4}$ Tomato + Broomrape + Watercress at $15 \mathrm{~g} / \mathrm{kg}$ soil

$\mathbf{T}_{5}$ Tomato + Broomrape + Watercress at $30 \mathrm{~g} / \mathrm{kg}$ soil

T6 Tomato + Broomrape + Watercress at $45 \mathrm{~g} / \mathrm{kg}$ soil
$\mathbf{T}_{7}$ Tomato + Broomrape + Mustard at $5 \mathrm{~g} / \mathrm{kg}$ soil

T8 Tomato + Broomrape + Mustard at $10 \mathrm{~g} / \mathrm{kg}$ soil

T9 Tomato + Broomrape + Mustard at $15 \mathrm{~g} / \mathrm{kg}$ soil

T10 Tomato + Broomrape + Mustard at $30 \mathrm{~g} / \mathrm{kg}$ soil

$\mathbf{T}_{11}$ Tomato + Broomrape + Mustard at $45 \mathrm{~g} / \mathrm{kg}$ soil

$\mathbf{T}_{12}$ Tomato + Broomrape + Basamid $0.2 \mathrm{~g} /$ pot

Table 6: Total glucosinolates content ( $\mu \mathrm{mol} / \mathrm{g}$ dry weight) and total phenolics ( $\mathrm{mg} / \mathrm{g}$ dry weight) in the extracts of the seed powder of both watercress and mustard.

\begin{tabular}{ccc}
\hline $\begin{array}{c}\text { Seed powder extracts } \\
\text { of }\end{array}$ & $\begin{array}{c}\text { Total content of glucosinolates } \\
(\boldsymbol{\mu} \text { mol/g dry weight) }\end{array}$ & $\begin{array}{c}\text { Total content of phenolic compounds (mg/g } \\
\text { dry weight) }\end{array}$ \\
\hline Watercress & 316.03 & 35.62 \\
Mustard & 288.59 & 43.62 \\
\hline
\end{tabular}

There is no doubt that the results of this work as well as our previous results showed clearly the possibility of using the seed powder of watercress or mustard as a successful tool for decreasing the weeds seed bank in the soil and also add more support to the idea of using the vegetative parts of the two mentioned plants as a cover crop on weed dynamics to subsequent cultivation (Jabran et al., 2015). Therefore, it is recommended to start controlling weeds associated with a certain crop from the previous crop cultivation season. 


\section{Conclusion}

We predict the possibility of using the seed powder of watercress or mustard as a powerful tool in controlling weeds and definitely decreasing the weed seed bank for the next crop. Therefore, more attention must be paid for the possibility of using the vegetative parts of the two mentioned plants as a cover crop on weed dynamics in subsequent cultivation. Moreover, weed control should start in the previous crop by monitoring, controlling and managing the weeds. This means that Brassicaceae family could be considered as a wise application of controlling weeds.

\section{References}

Ahmed, S.A., N.K. Messiha, R.R. El-Masry and M.A. T.El-Dabaa, 2020a. The dual allelopathic capacity of two Brassicaceae plants seed powder in controlling Orobanche crenata infesting Pisum sativum as well as stimulating its growth and yield. Bull. Nat. Res. Centre, 1-8. https://doi.org/10.1186/s42269-020-0276-6.

Ahmed, S.A.A., R.R. El-Masry, N.K., Messiha and K.G. El- Rokiek, 2018. Evaluating the allelopathic efficiency of the seed powder of Raphanus sativus L. in controlling some weeds associating Phaseolus vulgaris L. Int. J. Envir., 7(3): 87-94. http://www.curresweb.com/ije/ije/2018/87-94.pdf

Ahmed, S.A.A., N.K.Messiha, M.A.T., El-Dabaa and R.R. El-Masry, 2020b. The residual effects of two Brassicaceae seed powder on the following summer plants and associated weeds. Middle East J. Agric. Res., 9 (2): 479-490.

Al-Khatib, K., C., Libbey and R., Boydston, 1997. Weed suppression with Brassica green manure crops in green pea. Weed Sci., 45: 439-445. https://www.jstor.org/stable/4046046.

Angus, J. F., A.F. van Herwaarden and G.N. Howe.1991. Productivity and break crop effects of wintergrowing oilseeds. Aust. J. Exp. Agric., 31: 669-77.

Bangarwa, S.K. and J.K. Norsworthy. 2014. Brassicaceae cover-crop effects on weed management in plasticulture tomato. J. Crop Improv. 28, 145-158. https://doi.org/10.1080/15427528.2013.858381

Bialy, Z., W. Oleszek, J. Lewis and G. Fenwick, 1990. Allelopathic potential of glucosinolates (mustard oil glycosides) and their degradation products against wheat. Plant and Soil 129: 277-281. https://doi.org/10.1007/BF00032423

Bones, A.M. and J.T., Rossiter, 2006. The enzymic and chemically induced decomposition of glucosinolates.Phytochem., 67:1053-1067. https://dol.org/10.1016/j.phytochem.2006.02.024

Boydston, R. and A., Hang,1995. Rapeseed (Brassica napus) green manure crop suppresses weeds in potato (Solanum tuberosum). Weed Technol.,9: 669-675. DOI: https://doi.org/10.1017/S0890037X00024039

Choesin, D. N. and R. E. J. Boerner,1990. Glucosinolate exudation and allelopathy in Brassica napus L. effects of phosphorus and sulfur availability. Ohio J. Sci., 90 (Extra 2): 4.

Diouf, D. 2011. Recent advances in cowpea [Vigna unguiculata (L.) Walp.] "omics" research for genetic improvement. Afr. J. Biotechnol.,10: 2803-2810. DOI: 10.5897/AJBx10.015

El-Dabaa, M. A. T., S.A. Ahmed, N.K. Messiha and R.R. El-Masry, 2019.The allelopathic efficiency of Eruca sativa seed powder in controlling Orobanche crenata infected Vicia faba cultivar. Bull. National Research Centre, 43(37):1-8. https://doi.org/10.1186/s42269-019-0079-9

El-Masry, R.R. E.R. El-Desoki, M.A.T. El-Dabaa, N.K. Messiha and S.A.A. Ahmed, 2019. Evaluating the allelopathic potentiality of seed powder of two Brassicaceae plants in controlling Orobanche ramosa parasitizing Lycopersicon esculentum Mill. Plants. Bulletin of the National Research Centre, 43(101):1-8. https://doi.org/10.1186/s42269-019-0144-4.

El-Masry, R.R., N.K. Messiha, K.G. El- Rokiek, S.A. Ahmed and S.A. Mohamed, 2015. The allelopathic effect of Eruca sativa Mill. seed powder on growth and yield of Phaseolus vulgaris and associated weeds. Current Sci. Int., 4(4):485-490.

https://pdfs.semanticscholar.org/6713/b8c372001f157a0e129a7f4fb82db8d8775d.pdf

El-Rokiek, K.G., R.R. El-Masry, S.A.A. Ahmed, S.A. Mohamed and N.K. Messiha, 2018. Allelopathic effects of Allium sativum cloves on growth and yield of Helianthus annuus_associating Cyperus rotundus. Int. J. Env., 7(3):78-86. http://www.curresweb.com/ije/ije/2018/78-86.pdf 
El-Wakeel, M.A., S.A.A., Ahmed and E.R., El-Desoki, 2019. Allelopathic efficiency of Eruca sativa in controlling two weeds associated Pisum sativum plants. Journal of Plant Protection Research, 59 (2):1-7. DOI: https://doi.org/10.24425/jppr.2019.129283

El-Wakeel, M.A. and I.M., El-Metwally. 2020. Allelopathic potential of orange fruit wastes as a natural bio-herbicide in controlling canary grass and cheeseweed mallow infesting common bean plants. Pak. J. Weed Sci. Res., 26 (2): 179-193. DOI: https://doi.org/10.28941/pjwsr.v26i2.831

El-Wakeel, M.A., S.A. Ahmed, S. A. Mohamed and N.K. Messiha. 2020. Evaluation of Psidium guajava leaves and acetic acid as natural herbicides for controlling some weeds of Capsicum annuum crops. Pak. J. Weed Sci. Res., 26 (1): 100-115.

DOI: https://doi.org/10.28941/pjwsr.v26i1.816

Fahey, J.W., A.T. Zalcmann and P. Talalay. 2001. The chemical diversity and distribution of glucosinolates and isothiocyanates among plants. Phytochem., 56:5-51. doi: 10.1016/s0031-9422(00)00316-2.

Food and Agriculture Organization (FAO). 2012. Grassland species index. Vigna unguiculata http://www.fao.org/ag/AGP/AGPC/doc/Gbase/data/pf000090.htm (accessed 6 June 2012). https://doi.org/10.1186/s42269-020-0276-6

Haramoto, E.R. and E.R. Gallandt. 2004. Brassica cover cropping for weed management: A review, Renew, Agric. Food Syst. 19: 187-198.

Haramoto, E.R. and E.R. Gallandt, 2005. Brassica cover cropping: 1. Effects on weed and crop establishment. Weed Sci., 53: 695-701. DOI: https://doi.org/10.1614/WS-04-162R.1

Jabran, K. and M. Farooq. 2013. Implications of potential allelopathic crops in agricultural systems, allelopathy, Springer Berlin Heidelberg, pp. 349-385. https://link.springer.com/chapter/10.1007/978-3-642-30595-5_15

Jabran, K., G. Mahajan, V. Sardana and B.S. Chauhan. 2015. Allelopathy for weed control in agricultural systems. Crop Prot., 72: 57-65. http://dx.doi.org/10.1016/j.cropro.2015.03.004

Krishnan, G., D.L. Holshouser and S.J. Nissen, 1998. Weed control in soybean (Glycine max) with green manure crops. Weed Technol., 12: 97-102. https://europepmc.org/article/agr/ind21378975

Messiha, N.K., S.A. Ahmed, K.G. El-Rokiek, M.G. Dawood and R.R. El-Masry, 2013. The Physiological Influence of allelochemicals in two Brassicaceae Plant Seeds on the Growth and Propagative Capacity of Cyperus rotundus and Zea mays L. World Appl. Sci. J., 26 (9): 11421149. DOI: 10.5829 /idosi.wasj.2013.26.09.13548

Messiha, N.K., M.A.T., El-Dabaa, R.R. El-Masry and S.A.A., Ahmed, 2018. The allelopathic influence of Sinapis alba seed powder (white mustard) on the growth and yield of Vicia faba (faba bean) infected with Orobanche crenata (broomrape). Middle East J. Appl.Sci., 8 (2):418425.https://pdfs.semanticscholar.org/ed68/f0c44df009c0ef1aa6180e71667e43863d0f.pdf

Morra, M.J. and J.A. Kirkegaard, 2002. Isothiocyanate release from soil-incorporated Brassica tissues. Soil Biol. Biochem., 34: 1683-1690. DOI: 10.1016/s0038-0717(02)00153-0

Nasirullah and M.N. Krishnamurthy, 1996. A method for estimating glucosinolates in mustard/rape seeds and cake. J. Sci. Technol., 33(6): 498-500. http://ir.cftri.com/id/eprint/2475

Oliva, A., E. lahoz, R. Contillo and G. Aliotta. 2002. Effects of Ruta graveolens leaves on soil characteristics and early seedling growth of four crop species. Annals Appl. Biol., 141: 87-91. https://doi.org/10.1111/j.1744-7348.2002.tb00199.x

Petersen, J., R. Belz, F. Walker and K. Hurle. 2001. Weed suppression by release of isothiocyanates from turnip-rape mulch. Agron. J., 93:37-43. https://www.mssoy.org/uploads/files/agron-j-932001.pdf

Rauchberger, Y., S., Mokady and Cogan. 1979. The effect of aqueous leaching of glucosinolates on the nutritive quality of rapeseed meal. J. Food Agric., 30: 31-39.

https://doi.org/10.1002/jsfa.2740300107

Rice, A., J. Johnson-Maynard, D. Thill and M., Morra, 2007. Vegetable crop emergence and weed control following amendment with different Brassicaceae seed meals. Renew. Agri. Food Syst. 22: 204-212. DOI: $10.1017 /$ S1742170507001743.

Snedecor, G.W. and W.G. Cochran. 1980. Statistical Methods. $7^{\text {th }}$ Ed. pp.: 507. The Iowa State Uni. PRESS, Ames, Iowa.

Snell, F.D. and C.T. Snell, 1953. Colorimetric methods. Pp.:66 Volume 111. Organi, D. Van Nostrand Company, Inc. Toronto, New York, London. 
Teasdale, J.R. and R.B. Taylorson, 1986. Weed seed response to methyl isothiocyanate and metham. Weed Sci., 34:520-524. DOI: https://doi.org/10.1017/S0043174500067357

Vilhorde, B.W., M.E. Burin, V.H. Gandalfi, N.A. Barni, J.E. da S. Gomes and J.C Goncalves. 1985. Allelopathic effect of rapeseed (Brassica napus L. var. oleifera Metzg.) on rotation and succession of wheat and soybean. Agron. Sulriog., 21: 55-64.

Wolf, R.B., G.F. Spencer, and W.F. Kwolek, 1984. Inhibition of velvetleaf (Abutilon theophrastii) germination and growth by benzyl isothiocyanate, a natural toxicant. Weed Sci., 32:612-615. http://europepmc.org/article/AGR/GUA84132239

Zeng, R.S. 2014. Allelopathy- the solution is indirect. J. Chem. Ecol., 40: 515-516.

Zimdahl, R. L. 2013. Fundamentals of Weed Science, fourth ed. Academic Press. San Diego, CA, USA. https://www.elsevier.com/books/fundamentals-of-weed-science/zimdahl/978-0-12-394426-9 